\title{
Fostering Innovation in International Journalism Education with Social Media in Beijing
}

\author{
Chen $\mathrm{Li}$ \\ School of International Communications \\ Beijing International Studies University \\ Beijing, P. R. China \\ kirbychenli@glasgowalumni.net
}

\begin{abstract}
This paper aims to identify whether a newlyproposed learning mode, which integrates the use of social media, has been an effective method for innovating in journalism education. Based on a quantitative analysis of three consecutive surveys of 139 students who attended a course incorporating WeChat/Weibo, this paper finds that: (1) most students are satisfied with this learning mode, becoming familiar with social media production and interested in topics related to international affairs with professional pride also increased; (2) general interests in this field have not always developed into vocational ones, by which their willingness to pursue related journalist career are subsequently constrained. Future direction of this innovation should be more motivational and practice-centered, by integrating participatory elements from media outlets directly.
\end{abstract}

Keywords-Social media; teaching journalism; international affairs; WeChat; Weibo

\section{INTRODUCTION}

Undoubtedly, various forms of social media have been an integral part of our everyday life, through which people tend to keep updated of what has happened around the world as well as around themselves. Many scholars have argued from different cultural backgrounds that the ecology of news production/consumption has been greatly changed accordingly. For instance, Newman et. al. pointed out the growing synergy between news media and the Social-Networking Sites (SNSs) in recent years which significantly leads to new patterns of news readership in the UK [1]. To be specific, traditional media (both print and broadcast ones) have seized this opportunity of convergence by distributing their professional contents via channels of these SNSs, such as Facebook and Twitter accounts. Internet/Mobile users - who have subscribed those accounts - are able to receive any news updates from these news media promptly, and share them with/without comments in an interactive, networked way. The implication of this for journalism education will thus be explored in this paper.

\section{LITERATURE REVIEW}

The adoption of social media in higher education is not uncommon in recent years as well. For instance, Meredith from a perspective of business communication analyzed the feasibility of incorporating the idea of participatory learning (based on social media) into the MBA course [2]. Given the practical nature of these courses, he suggests that student projects should involve social-media platforms in which MBA students can be trained to produce and deliver company/product messages to actual clients. This pioneering attempt has indeed laid out a framework for academics from many other disciplines to follow.

Compared to those social-media marketing directors, media professionals who can use the SNSs and produce/tailor news contents skillfully are also urgently needed - which unquestionably leaves the training task of the latter directly to the courses established by the journalism school. In response to this call, Kothari and Hickerson surveyed a sample of journalism academics $(n=125)$ across the US universities to examine how social media have been incorporated into the design of their coursework, with comparison to related student feedback [3].

As they find, $65 \%$ academics have asked students to share articles from news media via SNSs as a part of routine practice for the course [3]. This aims not only to cultivate students' awareness for recent news, but also to provide real, good writing examples for them to follow. Meanwhile, 53\% academics intended to give students basic instructions on how to approach news sources via SNSs as well as on how to verify the information they provided. Besides news production, students are also required to demonstrate their operation/management skills by completing projects where news stories written by themselves should be promoted via SNSs.

It should be noted that $74 \%$ academics have used Twitter as a main tool/platform for student practice, due in part to Twitter's "news-featured/centered" advantage (e.g. immediate, informative/information-rich, insightful) over other social media [3]. According to a recent report by Pew Research Centre, $59 \%$ of Twitter users said they follow breaking news via Twitter in a real-time mode [4].

\section{METHOD}

The researcher, working at a local university in Beijing, asked his students who had enrolled in his course of "International News Reporting" in 2014, 2015 and 2016 to run a social media account on a group basis of three to five people 
respectively. They were required to publish their individual/team works, featuring various topics of international affairs, on any regular basis as they preferred. After the completion of this course, their overall attitudes and opinions towards this mode of learning were surveyed accordingly.

\section{A. Study One: WeChat}

WeChat, originally derived from the WhatsApp mode, has moved beyond an instant-messenger site, by incorporating the newsfeed feature that allows users to post and receive news/information from WeChat friends. Notably, WeChat users can also subscribe newsfeeds from any WeChat Official Account (aka. Facebook Pages) and retweet/post them to feed WeChat friends. In this sense, "one-to-many" (one WeChat Official account $\rightarrow$ many subscribers/followers) and "manyto-many" (mass self-centered newsfeeds) models, as shown in Fig. 1 below, explains why WeChat serves as one of the most powerful communicative platform in contemporary China.

Given its enormous communicative power, the researcher asked those students who enrolled in 2016 to run WeChat Official Accounts to publish international affair news they edited ("one-to-many"), as well as videos they shot. They were also required to retweet their works amongst their WeChat friends as widely as possible ("many-to-many"). Unlike the public visibility of Weibo (Chinese version of Twitter), WeChat users are mainly based on reliable private friendship. So this means anything you post can be taken seriously by your friends - the effects of which thus could be generated to an extent greater than on strangers. After the completion of this course, their overall attitudes and opinions towards this mode of learning in relation to the practice of journalism (as well as this journalist profession) were evaluated with the help of an 18-item questionnaire. In overall, 56 feedbacks were received.

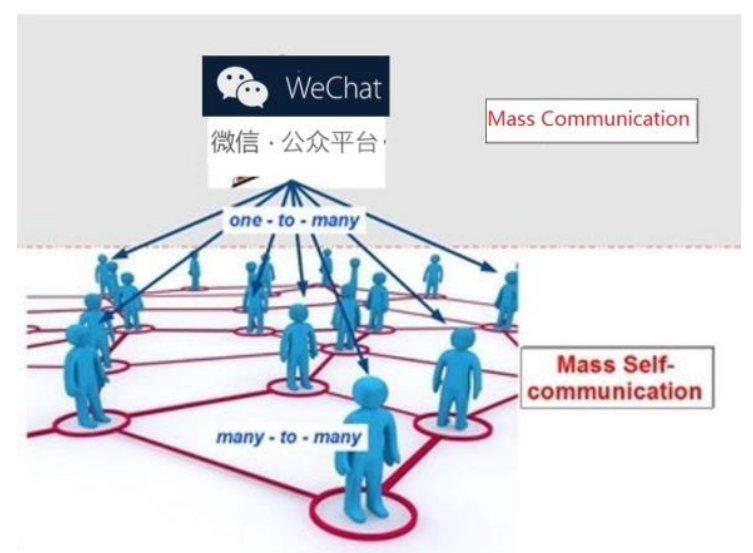

Fig. 1. Communication models of WeChat.

\section{B. Study Two: Weibo - Chinese version of Twitter}

Before this, the researcher had asked students enrolling in the same course to run Weibo accounts in the year of 2014 and 2015 respectively. As discussed earlier, Twitter is credited with immediacy and information-richness; so is the Weibo in the field of Chinese language. They were asked either (1) to post original news articles/commentary or (2) to retweet post from media outlets with their comments in the field of international affairs. Questionnaires were sent to them by the end of the course, with 41 and 42 questionnaires received respectively. That is to say, a sample of 83 journalism students relating to Weibo was studied.

\section{RESULTS}

\section{A. Levels of Familiarity with Production and Management}

In Study One, 39 students had intern experience in media outlets before enrolling in this course, amongst which 26 students worked in new media. As shown in Fig. 2 and Fig. 3, Study One finds most of them agreed they had become more familiar with the news production within the social media environment as well as with how to run a WeChat account.

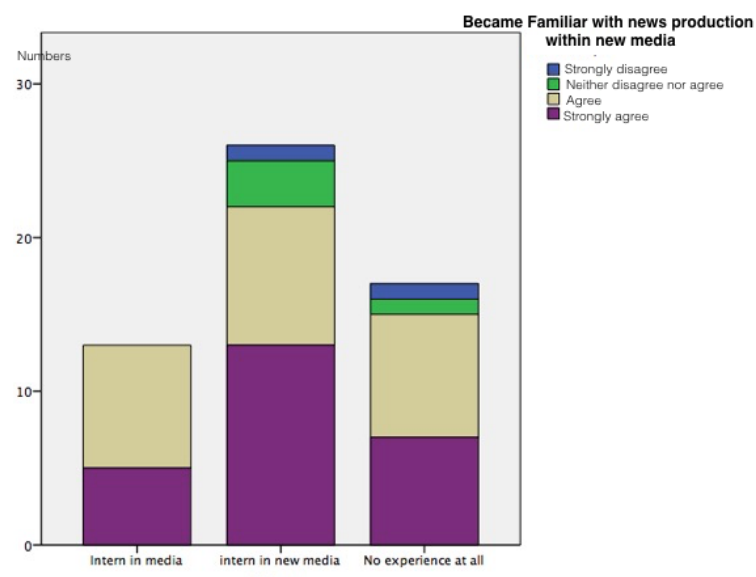

Fig. 2. Different levels of familiarity with the production in 2016.

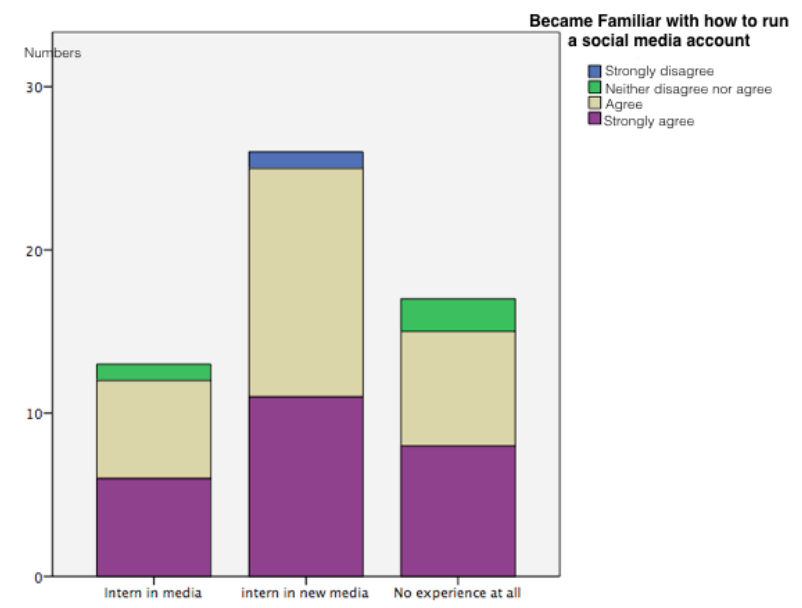

Fig. 3. Different levels of familiarity with how to run WeChat accounts.

As can be seen from Fig. 2 and Fig. 3, those students with new media experience are the group who are mostly satisfied with this mode of learning. Of those strongly favoring this innovative course, more than half have worked in this field before, due in part to their prior working experience that makes them feel necessary to practice more in the relevant course and make subsequent efforts. Only two students 
disapproved this method, of whom one had worked in new media before and thus might think nothing new could be found in this course compared to her previous experience.

Compared to the Class in the Year of 2016, Study Two mainly focused on Weibo, Chinese version of Twitter in the year of 2014 and 2015 respectively. One of the reasons why WeChat was not chosen is that its feature of Official Account (aka. Facebook Pages) were not widely adopted at that time. As shown in Fig. 4, most students (34 students in 2014 and 25 students in 2015) - similar to that of 2016 - agreed this mode of learning had helped them to better understand news production within the environment of new media. There is no significant difference between students in the year of 2014 and that of 2015 in terms of their evaluations about this mode of learning.

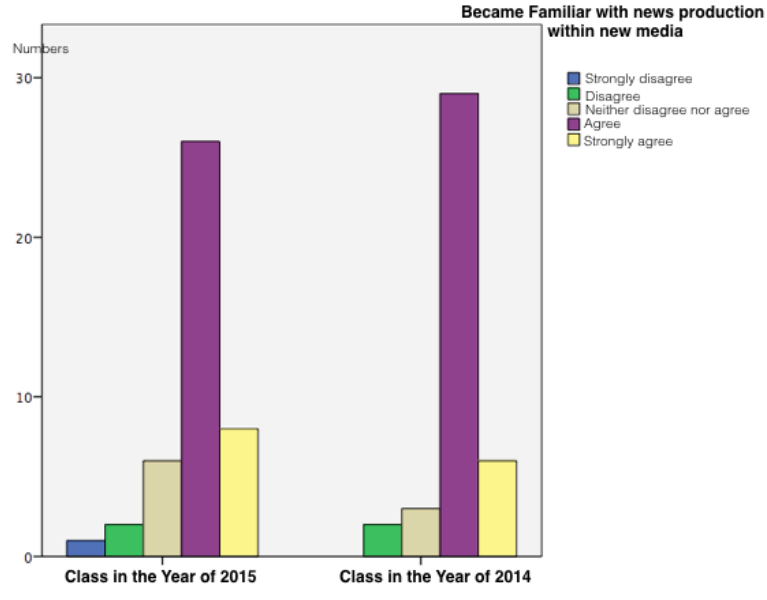

Fig. 4. Different levels of familiarity with the production in 2014 and 2015.

\section{B. Reporting International Affairs: Interests and Behaviors}

As mentioned before, those students are required to focus on the field of international affairs by posting relevant news summaries and/or commentaries. This is also one of the learning objectives set by the subject syllabus. It is well understood some students, though majored in international journalism, may find it difficult to become interested in this field initially. So, another aim of this study is to find out whether they have become interested in the field of international affairs and related reporting, as well as whether there have been significant changes

1) Interests in International Affairs and Related Reporting: Study One finds most students tended to become interested in the field of international affairs and related reporting. As shown in Fig. 5, those students who had experience in new media (i.e. 23 students) tended to believe that they had become interested due to their participation in this course. But it should be noted that more students became less interested or showed no interest in reporting international affairs. Fig. 6 especially shows five more students of those who had worked in traditional media turned less interesed in this kind of reporting. This can be casued by their current reportage which might be urelated to international affairs at all. Meanwhile, two more students in media media showed their dissapproval.

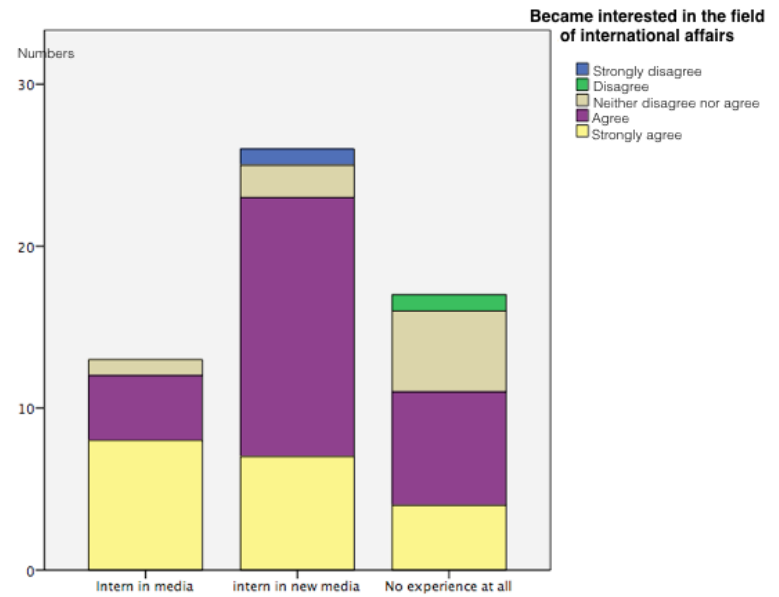

Fig. 5. Different levels of interests in international affairs in 2016.

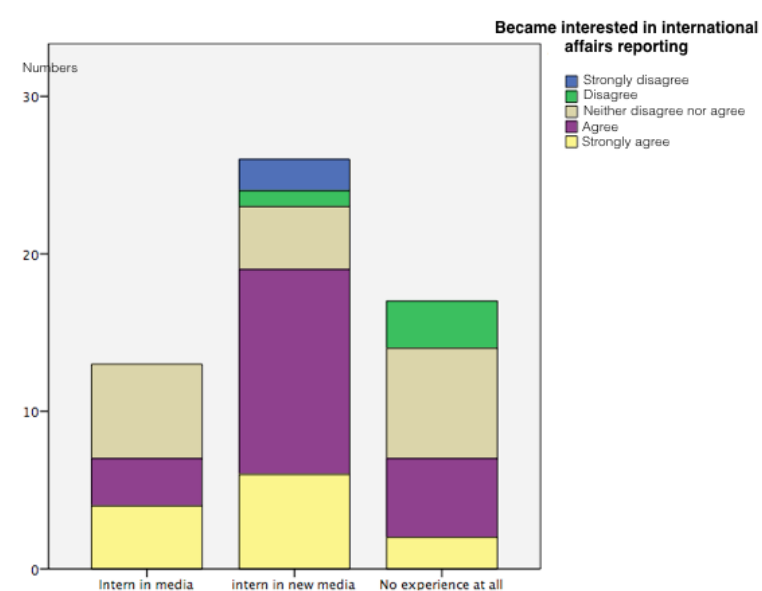

Fig. 6. Different levels of interests in international affairs reporting in 2016.

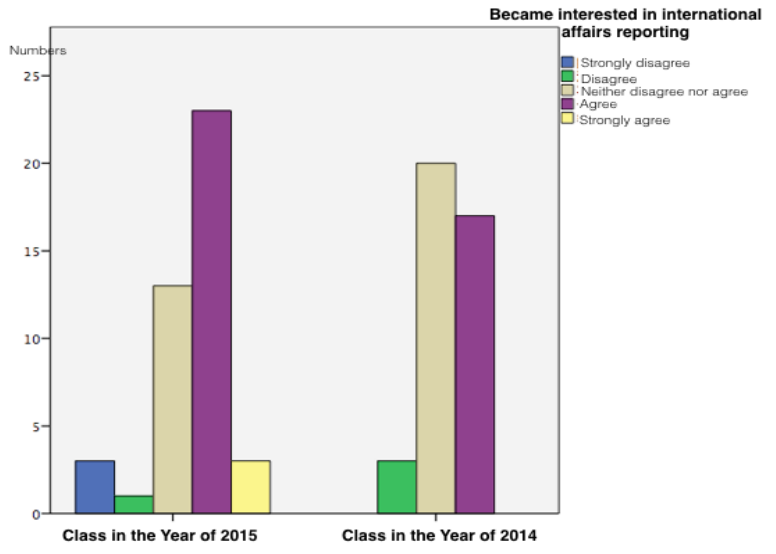

Fig. 7. Weibo: Different levels of interests in international affairs reporting.

Regarding Weibo, Study Two mainly examined their attitudes towards the international affairs reporting. As shown in Fig. 7, the number of "strongly agree" students decreased.

2) Correlations between Post-Course Activities and Interests: Both sudies also examine correlation between interests and their behaviors. To be specific, it is assumed students who show more interests tend to be more involved in 
activities relating to international affairs, such as keeping an eye on the development of recent events, checking relevant information sources, etc.

TABLE I. CORRELATION BETWEEN ACTIVITIES AND INTERESTS IN 2016

\begin{tabular}{|l|c|c|}
\hline \multirow{2}{*}{} & \multicolumn{2}{|c|}{ Interests in: } \\
\cline { 2 - 3 } & $\begin{array}{c}\text { International } \\
\text { affairs }\end{array}$ & $\begin{array}{c}\text { Related } \\
\text { Reporting }\end{array}$ \\
\hline $\begin{array}{l}\text { Keepin an eye on the coverage of } \\
\text { international affairs and } \\
\text { subsequent development everyday }\end{array}$ & $.550^{* *}$ & $.311^{*}$ \\
\hline
\end{tabular}

Table I shows the correlations between interests in certain coverage and behaviors of related news consumption. Clearly, when students developed more interests in the field international affairs, they tended to keep themselves informed of related topics they were interested in - there was a strong correlation shown above. Meanwhile, their level of interests in related reportage was moderately correlated to such behaviors. In other words, their interests in this field could be cultivated through this course, which thus continues to motivate them to reinforce it through certain behaviors. However, there have been a number of journalism students among them who were not so interested in reporting itself as others. Lack of intern opportunities could be one of the reasons why general interested has not been able to develop into vocational ones.

TABLE II. CORRELATION BETWEEN ACTIVITIES AND INTERESTS (WEIBO)

\begin{tabular}{|l|c|c|}
\hline \multirow{2}{*}{} & \multicolumn{2}{|c|}{$\begin{array}{c}\text { Interests in International } \\
\text { Affairs Reporting }\end{array}$} \\
\cline { 2 - 3 } & $\begin{array}{c}\text { Class in 2015 } \\
(\mathbf{n = 4 2})\end{array}$ & $\begin{array}{c}\text { Class in 2014 } \\
(\mathbf{n = 4 1})\end{array}$ \\
\hline $\begin{array}{l}\text { Frequency of checking Weibo } \\
\text { contents relating to international } \\
\text { affairs }\end{array}$ & $.419^{* *}$ & $.396^{*}$ \\
\hline
\end{tabular}

Table II from another dimension illustrates that interests can motivate students to seek relevant contents actively. This is consistent with findings from previous studies about web information-seeking behaviors [5]. The researcher surveyed students in the year of 2014 and 2015, both of which indicate there were moderate correlations - though the latter is a little bit more correlated. So it means their patterns of news content consumption might have been affected by the involvement in this course: (1) further developments in the topics they had previously focused on could drive their interests and lead to this; and (2) the element of international affairs may have become an integral part of their consumption pattern.

\section{Building Professional Pride and Confidence}

Both Study One and Study Two also aim to explore the role of such course in contributing to the construction of professional identity. For example, Study One finds those who had showed more interests in becoming a professional reporter in this field of international affairs tended to strengthen their willingness to pursue related career in this field. As shown in Table III, such willingness is moderately correlated to their vocational interests in international affairs reporting. In comparison, general interests in this field did not work out in this way. This also emphasize the necessity of developing vocational interests intentionally, elements of which can be well integrated into the design of the course. Furthermore, Strong Interest Inventory (SII) can be introduced before their enrolling for this course, helping them to identify whether their interests match the profession of journalist or not [6]. On the basis of this, this course would help those have vocational interests in journalism to familiarize with the field of international affairs, to further identify whether this is what they want or not. Meanwhile, those who are not interested in becoming as journalists at all can also develop/maintain their general interests in related topics of international affairs.

TABLE III. CORRELATION BETWEEN INTERESTS AND FURTURE CAREER

\begin{tabular}{|l|c|c|}
\hline \multirow{2}{*}{} & \multicolumn{2}{|c|}{ Interests in: } \\
\cline { 2 - 3 } & $\begin{array}{c}\text { International } \\
\text { affairs }\end{array}$ & $\begin{array}{c}\text { Related } \\
\text { Reporting }\end{array}$ \\
\hline $\begin{array}{l}\text { Level of willingness to pursue } \\
\text { his/her journalist career in the field } \\
\text { of international affairs }\end{array}$ & .196 & $.359^{* *}$ \\
\hline
\end{tabular}

Besides interests, the sense of achievement has been argued as one of the most important factors that can motivate people to continue engaging in their chosen career paths [7]. Thus Study One asked students to rate their sense of achievement derived from their participation in this WeChat project and especially from those articles/videos produced by themselves. As shown in Fig. 8, most students seemed satisfied with what they had achieved on this platform of WeChat, of whom 29 students showed their approval strongly. Besides this, this study also focused on the features embedded with the new media that can contribute to the construction of sense of achievement. That is around the immediate metrics on the audience feedback, i.e. how many people viewed your post and how many of them liked it. Thus we assume such positive, immediate audience feedback can motivate students' sense of achievement as well.

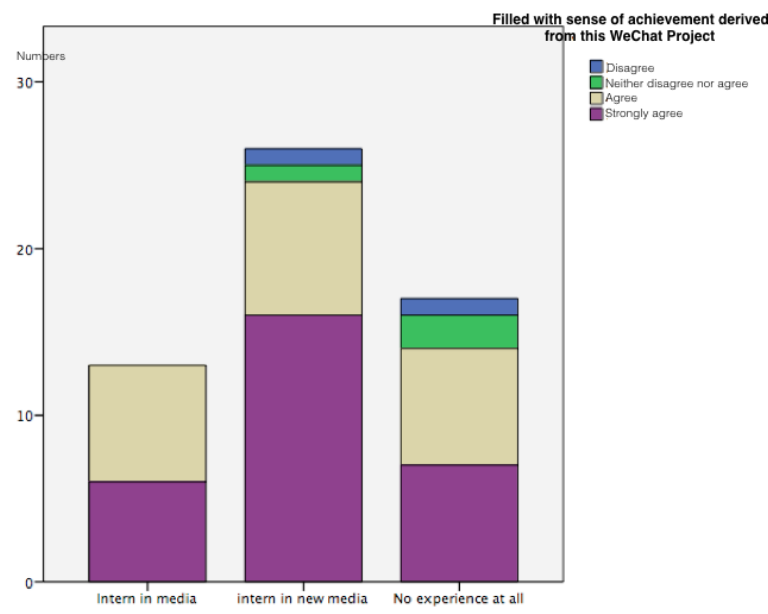

Fig. 8. Different levels of sense of achievement in 2016.

Indeed, 23 students agreed, with further strong approval from another 24 students - almost $84 \%$ students in the year of 2016 felt sense of achievement derived from positive audience feedback on the platform of WeChat. 
TABLE IV. CORRELATION BETWEEN SENSE OF ACHIEVEMENT DERIVED FROM PUBLISHED WORKS /AUDIENCE FEEDBACK AND DETERMINATION TO

\begin{tabular}{|c|c|c|}
\hline & \multicolumn{2}{|c|}{ Sense of achievement derived from: } \\
\hline & $\begin{array}{c}\text { Published } \\
\text { works }\end{array}$ & $\begin{array}{l}\text { Audience } \\
\text { feedback }\end{array}$ \\
\hline $\begin{array}{l}\text { Professional pride and } \\
\text { confidence as a journalist in } \\
\text { an era of media convergenc }\end{array}$ & $.603^{* *}$ & $.675^{* *}$ \\
\hline $\begin{array}{l}\text { Level of willingness to pursue } \\
\text { his/her journalist career in the } \\
\text { field of international affairs }\end{array}$ & $.289^{*}$ & .153 \\
\hline
\end{tabular}

Study One further explored the impact of such senses of achievement upon professional pride/confidence as well as career choices. Undoubtedly, their professional pride and confidence can be boosted with the increase of sense of achievement, which are proven as being strongly correlated in Table IV. That also suggests the element of "rewards" - to further strengthen the sense of achievement -can also be integrated in the future course design. Table IV also shows those senses of achievement derived from published articles/videos can be weakly correlated to such willingness, while those derived from audience feedback cannot. As shown in Table III, students' willingness to pursue related journalist career in the field of international affairs is moderately correlated to their vocational interests in international affairs reporting. So, within this "vocational interest" framework, it is worth exploring whether "sense of achievement" could serve as a further factor to strengthen their willingness.

TABLE V. COMPARISON BETWEEN THOSE WHO ARE STRONGLY INTERESTED AND THOSE WHO ARE INTERESTED IN INTERNATIONAL AFFAIRS REPORTING AND THOSE WHO ARE JUST INTERESTED

\begin{tabular}{|l|c|c|c|}
\hline & \multirow{2}{*}{$\begin{array}{c}\text { Interested in } \\
\text { international } \\
\text { affairs } \\
\text { reporting }\end{array}$} & \multicolumn{2}{|c|}{$\begin{array}{c}\text { Sense of achievement } \\
\text { derived from: }\end{array}$} \\
\cline { 3 - 4 } & $\begin{array}{c}\text { Published } \\
\text { works }\end{array}$ & $\begin{array}{c}\text { Audience } \\
\text { feedback }\end{array}$ \\
\hline $\begin{array}{l}\text { Level of } \\
\text { willingness to } \\
\text { pursue his/her } \\
\text { journalist } \\
\text { career in the } \\
\text { field } \\
\text { international } \\
\text { affairs }\end{array}$ & $\begin{array}{c}\text { Strongly } \\
\text { intrested } \\
(\mathrm{n}=12)\end{array}$ & .35 & -.018 \\
\cline { 3 - 4 } & $\begin{array}{c}\text { Interested } \\
(\mathrm{n}=21)\end{array}$ & .236 & .252 \\
\hline
\end{tabular}

Result in Table V, however, does not provide sufficient evidence to indicate that these factors are significantly correlated to their willingness of career choices in this specific field. But previous literatures have emphasized the important role of "sense of achievement" in the career choices and development [7]. Why did it not work here? One of the reasons could be this "sense of achievement" cannot be counted as an "authentic" one carrying the same weight as those in the career development. This, in essence, poses a challenge to such practice-oriented courses: Can this practice be more associated with the real working environment, such as the media outlet in this case? Can these media outlets help to publish some quality articles/videos from students directly? If so, it would increase an authentic sense of achievement that subsequently motivates students in a career-building manner.

\section{DISCUSSION AND CONCLUSION}

In overall, most students between the Year of 2014 and 2016 are satisfied with this learning mode that integrates the platform of social media into practice. To be specific, $80.3 \%$ students in Study One and $84.3 \%$ in Study Two agreed to recommend this mode of learning to other students of similar courses. Notably, students in Study One with WeChat experience seemed more active than those using Weibo, which might be caused by higher degree of satisfaction, not only with this learning mode but also with the platform this learning mode has been built on - given the rise of WeChat with more convenience and popularity amongst college students

As shown previously, the adoption of social media, both WeChat and Weibo, in this course of "International News Reporting" between 2014 and 2016 seemed succinctly effective in terms of helping students:

- Become more familiar with the news production within the social media environment, as well as with how to run a social media account featuring international news

- Develop more interests in the field of international affairs and thus tend to keep themselves informed about relevant topics actively

- Build professional pride and confidence as a journalist in general, with certain senses of achievement increased

However, their willingness to pursue journalist career in the field of international affairs are relatively limited practice elements (e.g. intern and publishing opportunities) from media outlets are needed to be integrated into this course in the future.

\section{REFERENCES}

[1] N. Newman, W. H. Dutton, and G. Blank, "Social media in the changing ecology of news production and consumption: The case in Britain," Annual Conference of the International Communication Association, May 2011.

[2] M. J. Meredith, "Strategic communication and social Media: An MBA course from a business communication perspective," Business Communication Quarterly, vol. 75, pp. 89-95, 2012.

[3] A. Kothari and A. Hickerson. "Social media use in journalism education faculty and student expectations." Journalism \& Mass Communication Educator, vol. 71 (4), pp. 1-12, 2015.

[4] Pew Research Center, "The evolving role of news on Twitter and Facebook", 14 July 2015.

[5] K. Martzoukou, "A review of web information seeking research: Considerations of method and foci of interest," Information Research: An International Electronic Journal, vol. 10 (2), January 2005.

[6] D. A. C. Donnay, "E. K. Strong's legacy and beyond: 70 years of the Strong Interest Inventory," The Career Development Quarterly, vol. 46(1), pp. 2-22, 1997.

[7] J. Sturges, "What it means to suceed: Personal ceonceptions of career success held by male and female managers at different ages," British Journal of Management, vol. 10 (3), pp.239-252, 1999 